DOI: $\underline{10.20472 / T E .2015 .3 .4 .006 ~}$

\title{
PERCEPTION OF TEACHERS AND STUDENTS TOWARDS THE FUNCTIONALITY OF SEMESTER SYSTEM AT UNIVERSITY LEVEL IN THE CONTEXT OF PAKISTANI SOCIAL AND ADMINISTRATIVE SET-UPS
}

\author{
LUBNA SHOUKAT, WAHEED MUHAMMAD
}

\begin{abstract}
:
The present research was conducted to find out the functionality and compatibility of the semester system at University level in the light of perceptions of Teachers and students with the existing specific Pakistani social norms and administrative structure. Pakistani educational institutions have been operating annual and composite systems for a long time, and these are still in operation in various universities especially for private students. The prevailing majority of teachers and administrative personnel studied under the annual system and were not formally trained to run semester system.

HEC directed Universities to introduce semester system almost a decade ago. This system is quite different in its philosophy, composition and implementation strategy. Semester system gives more freedom and flexibility to the teachers in deciding teaching-leaning activities ranging from designing the curriculum to the evaluation of the performance of students. The data showed that teachers used this freedom to gain more authoritative control, take less number of lectures and manipulate their biases. The academic and administrative priorities are different, and many compromises have to be made to counter the external and internal pressures and to cover the inefficiencies of the system. Irregularities in the academic calendar are due to lack of planning, inappropriate monitoring system, political instability and strikes. However, a $73.7 \%$ of students were satisfied with the fairness of the teachers in evaluating students' performance. Almost same percentages of teachers and students showed their satisfaction with the standard and knowledge structure of the students. The findings of the research showed a strong need for revamping the system according to its natural trends and to countering the negatively affecting social and administrative norms.
\end{abstract}

\section{Keywords:}

Semester system, Curriculum, Teaching methods, Evaluation, Social system and Administrative set-up

\section{Authors:}

LUBNA SHOUKAT, The Islamia University of Bahawalpur, Pakistan, Austria, Email: mwlubna@hotmail.com WAHEED MUHAMMAD , The Islamia University of Bahawalpur, Pakistan, Austria, Email: mwlubna@hotmail.com

\section{Citation:}


LUBNA SHOUKAT, WAHEED MUHAMMAD (2015). Perception of teachers and students towards the functionality of semester system at university level in the context of Pakistani social and administrative set-ups. International Journal of Teaching and Education, Vol. III(4), pp. 68-80., 10.20472/TE.2015.3.4.006 


\section{Introduction}

Every society follows a culture consisting of specific ideas, customs, traditions, attitudes, values that designate it a unique identity. The members of society not only endorse them but also pass them down from generation to generation through the process of socialization. These cultural norms, values and ideas regulate the behavior patterns of people. These behaviors, in turn, play a vital role to develop the functioning style of various systems in society to run different aspects of social life like politics, economics, or education. These functioning styles or behaviors reflect certain mentalset or social psyche of the people and thus shape the system into a unique management and working environment. This mental-set tries to reshape any new idea introduced in the system according to its very nature and sometimes changes the entire spirit of that idea.

Every society, particularly the developing one, borrows ideas or systems from other developed societies that originally developed them according to their social norms and approaches. Certain measures should be taken in the implementation of these borrowed ideas in a new social set-up to save their spirit otherwise it would be difficult to run them efficiently and to extract amicable consequences. In this article, our concern is the analysis of the implementation of semester system, a borrowed system, in Pakistani higher educational institutions.

First, we analyze the nature of Pakistani culture and its impact in characterizing its people's mental approach. Secondly, we will analyze the nature and requirement of semester system. These both aspects would provide a picture to discuss whether this system is being run according to its spirit in the context of Pakistani cultural attributes.

\section{Pakistani Cultural Ambience}

If the name of a society comes in mind, it gives a picture of the unique characteristic of its culture, for example, Chinese Society, Japanese Society, American Society and Pakistani society.

Society and culture coexist and inseparable. There is no society without culture and vice versa. Culture is an overall mental programming and basis of identification among groups (Hofstede, 1994). Pearson (1949) viewed culture as patterns of behavior as a result of human interaction and transferred down to generations socially.

The behaviors deal with a variety of aspects of human life like moral, intellectual and spiritual by the existing norms and values. People imbibe these values and ideas and show through their behavior. Therefore, these values and norms define the lifestyle and social pattern of the groups.

The understanding and categorizing the culture enables us to:
"1. Predict a culture's behavior
2. Clarify why people did what they did
3. Avoid giving offense, 4.search for some kind of unity, 5.standardize policies, and 6. Perceive neatness and Ordnung" (Lewis, 2006, p. 29).
Lewis model explains every culture in the world under three broad categories-Linear- active, multi-active and reactive. Multi-active cultures are very flexible. Multi-active people pretend to follow the schedule of work and punctuality. These people are extrovert, talkative, impatient, plan grand outline only, and work several things at a time (Lewis, 2006). Lewis places Pakistani culture under this category. 
Edward T. Hall's (1976) proposed model places the cultures on a continuum of high versus low context approach. In High context cultures, people closely involve with each other, and there exists a strong bond among them.

Pakistani society is high-context, patriarchal and hierarchal in nature. People usually value others with respect to a designation, age, sex and level of income. The people older in age are given more respect and valued to be wise. The senior male member of the family enjoys the headship of the family and controls the family's resources and behaviors of the members. His decisions are obligatory for the family members to be followed (Burki, 2015).

The empirically established dimensions of culture under the cultural dimensions theory presented by Hofstede (2001) provide a framework for the analysis of culture.

This theory analyzes the cultures under the dimensions of power distance, individualism versus collectivism, masculinity versus femininity, uncertainty avoidance, and indulgence. The corresponding values for these dimensions regarding Pakistani culture are 55, 14, 50, 70, and 0 respectively (Geert-hofstede.com, 2015).

Power distance is the acceptance level of the unequal distribution of power by the less powerful people in the society (Hofstede, 1991). The intermediate score of 55 on power distance makes difficult to determine a preference for Pakistani culture in this dimension. Pakistani society, with a very low score of 14 on individualism versus collectivism, appears to be collectivistic in nature. In collectivistic society, people prefer group interest and over-ride the societal rules and regulations. The score of 50 on masculinity dimension of Pakistani society does not show any preference either for masculinity or femininity. Masculine society tends to be assertive, competitive, and highly ambitious while femininity caring for others and quality of life. Pakistani society with a high score of 70 on avoiding uncertainty dimension tends to be more emotional and not readily accept the change.

Pakistan with an extremely low score of 0 on indulgence is rated as a very restrained society-a society that tends to be cynicism and pessimistic (Geert-hofstede.com, 2015).

\section{Semester System and its Requirement}

Various academic and examination systems are in practice in educational institutions across the world. Presently, the semester system is the most widely adopted one. In Pakistan, different educational institutions run different academic and examination systems.

The schools and colleges under government administration are being run under the annual system while the universities and degree awarding institutions have adopted semester system. However, some departments in universities are still maintaining the old annual system.

The annual and semester systems work under quite different philosophies, and the requirements of these are also different. Pabla (2014) explained the rationale of the semester system as "to impart enhanced values" to our students because the system and time need "Continuous Learning \& Assessment, Interdisciplinarity, Global movement of students . . . and conformity with Academic Practice \& Procedures" (p.173). Pabla (2014) also mentions the conditions to run the semester system effectively as "well-designed curriculum, in time course completion, regularity, constructive feedback, accessibility of teachers, availability of resources, transparency in evaluation, and timely declaration of results" (p.173). 


\section{Nature of Administration in Pakistani Institutions}

It is already discussed that the Pakistani society is hierarchical, top-down and hightext in nature. Its reflection can also be seen in the administration of educational institutions. Oplatka (2004) elaborates the relationship of cultural and social values which determines the patterns of behaviors of institutional and departmental heads. $\mathrm{He}$ describes that, in most developing countries the principals are autocratic in their leadership style, i.e., "the principals demand from subordinates unquestionable obedience to authority, use power as a zero-sum commodity and tend to do things on their own" (Oplatka, 2004, p.438). This style predominantly prevails in Pakistani educational institutions where "principals preside over very flat structures with relatively few opportunities for delegation" (Oplatka, 2004, p.438).

The Universities are no exceptions. As the universities in Pakistan are autonomous administrative bodies, the vice chancellors enjoy the unlimited and unquestioned powers one can just dream. He is the sole authority who unequivocally decides whatever he intends to. The other authorities behave in the same way in universities, and there is a symbolic participation of teachers in the decision-making and implementation.

\section{Objectives}

The purpose of the present study is to understand and analyze the Students' and Teachers' Perception towards Semester System concerning:

a) The functioning of semester system at university level

b) The effects of social and administrative environments in running the semester system.

\section{Methodology}

The survey method based on the semi-structured questionnaires was employed. The present study is delimited to students and teachers of Islamia University of Bahawalpur, Pakistan. It included the population of teachers and students of science, social science, and engineering departments.

The sample was selected on non-probability convenience method. Two separate questionnaires-one for teachers and one for students- were developed and administered. A large number of teachers and students were contacted, but 48 teachers and 209 students completed the questionnaires.

The administrative and social set-ups in all most all the public sector universities in Pakistan in general and in Punjab, the largest province, in particular, are same; and same is the case with a social environment. Therefore, the working environment, patterns of administrative hierarchy and decision making are all in common to the greater extent. On the basis of these similarities, the results may be applied to other public sector universities as well.

\section{Results and Discussion}

\subsection{Course Coverage and Regularity and Punctuality}

Syllabus coverage and regularity of classes are very important and intimately associated with each other. Credit hours are allocated in semester system according to the time needed to cover the course in stipulated time. There should be no question of non-coverage of course contents if time schedule is strictly observed. Any 
irregularity in holding classes will result in less coverage of syllabus that is against the essence of semester system.

Table- 1: Responses towards Course Coverage and Regularity of Classes

\begin{tabular}{|c|c|c|c|c|c|c|c|c|}
\hline \multirow[t]{2}{*}{ Item } & \multicolumn{3}{|c|}{$\begin{array}{l}\text { Level of course } \\
\text { contents coverage } \\
\text { within stipulated time }\end{array}$} & \multicolumn{3}{|c|}{$\begin{array}{l}\text { Level of Regularity } \\
\text { and Punctuality of } \\
\text { Teachers (in \%) }\end{array}$} & \multicolumn{2}{|c|}{$\begin{array}{l}\text { System to monitor the } \\
\text { course coverage by } \\
\text { teaches (in } \% \text { ) }\end{array}$} \\
\hline & $70 \%$ & $90 \%$ & $100 \%$ & $70 \%$ & $90 \%$ & $100 \%$ & Yes & NO \\
\hline $\begin{array}{l}\text { Teachers' } \\
\text { Responses (in \%) } \\
\mathrm{N}=48\end{array}$ & 8.3 & 54.2 & 37.5 & 8.3 & 54.2 & 37.5 & 33.3 & 66.7 \\
\hline $\begin{array}{l}\text { Students' } \\
\text { Responses (in \%) } \\
\mathrm{N}=209\end{array}$ & 50.2 & 38.3 & 11.5 & 52 & 32.2 & 15.8 & & \\
\hline
\end{tabular}

The responses of both teachers and students in table-1 regarding the course coverage show a noticeable difference among the teachers and students on issues of the regularity of teacher and the completion of course content.

A relatively high percentage (37.5\%) of teachers agreed that they could cover $100 \%$ course contents than a very small percentage of students $(11.5 \%)$. On the other side, a high response $(50.2 \%)$ of students evinces that teachers covered at most $70 \%$ of course contents as compared to a very low ratio (8.3\%) of teachers. It will give a more concise picture if we add up responses of both teachers and students on $90 \%$ and $100 \%$ levels of course coverage, which are $91.7 \%$ of teachers and $49.8 \%$ of students. It means $91.7 \%$ of teachers claimed that they covered the course between $90-100 \%$ while $49.8 \%$ of students did not conclude so.

The Table-1 depicts the similar trends regarding the regularity of the classes. $37.5 \%$ of teachers agreed that they held their classes 100\% while the students disagreed considerably, and only $15.8 \%$ for student conceded that teachers held their classes by $100 \%$. This data correlate the data regarding the course coverage and validate each other. A significant number of students, $52 \%$, revealed that teachers are $70 \%$ regular in holding their classes.

A high percentage of teachers, $66.7 \%$, pointed out the non-existence of any monitoring system to check whether the teacher has completely taught the syllabus or not.

\subsection{Reasons of Less Coverage of Syllabus}

It seems very important to highlight the reasons responsible for less coverage of courses in stipulated time. The following table-2 delineates the reasons mentioned by the teachers that relate to haphazardness, uncoordinated activities and mismanagement within the system and at the country level.

The other critical aspect that is related to power-play in the system will be highlighted in the discussion. 
Table-2: Reasons of Less Coverage of Course Contents

1. Mismatch of Syllabi with students' academic level. Sometimes syllabi are too advanced.

2. Unexpected strikes and other disciplinary issues

3. Too many public/incidental holidays

4. Students remain busy in non-academic activities.

5. Uneven holidays during the semester

6. Irrelevant topics in the syllabus

7. Other administrative and official assignments of the teachers

8. Short semester duration

9. Unavoidable unstable political and security situations

These are the genuine reasons that are affecting negatively on the proper functioning of the system and are beyond the control of teachers to avoid them.

\subsection{Properly Developed Syllabus and Availability of its official copy}

Table-3: Responses towards Properly Developed Syllabi \& Availability of official copy

\begin{tabular}{|l|l|l|l|l|l|l|}
\hline & \multicolumn{3}{|l|}{ Teachers' Responses (in\%) N=48 } & \multicolumn{2}{l|}{$\begin{array}{l}\text { Students' Responses (in \%) } \\
\text { N=205 }\end{array}$} \\
\hline & Available & $\begin{array}{l}\text { Not } \\
\text { Available }\end{array}$ & $\begin{array}{l}\text { No } \\
\text { Comment }\end{array}$ & Yes & No & $\begin{array}{l}\text { No } \\
\text { comment }\end{array}$ \\
\hline $\begin{array}{l}\text { Official Copy of } \\
\text { Syllabus }\end{array}$ & $83.3 \%$ & $16.7 \%$ & - & $80 \%$ & $17.1 \%$ & $2.9 \%$ \\
\hline $\begin{array}{l}\text { Properly } \\
\text { Designed } \\
\text { Syllabus }\end{array}$ & $77.1 \%$ & $18.8 \% \%$ & $4.2 \%$ & $73.2 \%$ & $21 \%$ & $5.9 \%$ \\
\hline
\end{tabular}

The perusal of table-3 reflects that almost same percentages of both teachers $(83 \%)$ and students (80\%) responded positively to the availability of an official copy of the syllabus. Nearly equal percentages of both groups of respondents, $77 \%$ teachers and $73 \%$ students, viewed the syllabi as properly designed. However, the percentages of teachers and students $(16.7 \& 17.1)$ who responded against the availability of official copy of syllabi while $18.8 \%$ teachers and $21 \%$ of students who assessed syllabi as improperly designed cannot be ignored.

On exploring what strategy the teachers adopt when an official copy of syllabi are not available, the teachers explained their ways like using HEC recommended syllabi downloaded from HEC website or self-designed syllabi. It is a point to note that in either of the cases, the syllabus will be unofficial because it has not been approved by relevant authority of the university.

\subsection{Ramification of Semester System}

The Table-4 reveals a picture the semester system is portraying after being implemented in higher educational institutions in Pakistan. 
Table-4: Ramification of Semester System

\begin{tabular}{|c|c|c|c|c|c|c|c|c|c|}
\hline \multirow{2}{*}{ No. } & \multirow{2}{*}{ Items } & \multicolumn{4}{|c|}{$\begin{array}{l}\text { Teachers' Response } \\
\text { (in \%) N=48 }\end{array}$} & \multicolumn{4}{|c|}{$\begin{array}{l}\text { Students' Response } \\
\text { (in \%) N= } 209\end{array}$} \\
\hline & & SS & $S$ & DS & SD & SS & $S$ & DS & SD \\
\hline 1 & $\begin{array}{l}\text { The curriculum is relevant to } \\
\text { produce the desired skills and } \\
\text { efficiency in students to match } \\
\text { the needs of the market. }\end{array}$ & 25 & 45.8 & 29.2 & 0 & 27.8 & 51.7 & 16.3 & 4.3 \\
\hline 2 & $\begin{array}{l}\text { Teachers are fair enough in } \\
\text { evaluating (grading) students' } \\
\text { performance. }\end{array}$ & 45.8 & 54.2 & 0.0 & 0 & 14.4 & 59.3 & 23.4 & 2.9 \\
\hline 3 & $\begin{array}{l}\text { The semester system has } \\
\text { promoted the more } \\
\text { authoritative attitude in } \\
\text { teachers }\end{array}$ & 29.2 & 54.2 & 4.2 & 12.5 & 26.8 & 56.0 & 12.9 & 4.3 \\
\hline 4 & $\begin{array}{l}\text { In semester system the } \\
\text { teachers manipulate their } \\
\text { biases (favoritism and } \\
\text { victimization). }\end{array}$ & 25.0 & 54.2 & 8.3 & 12.5 & 17.2 & 47.4 & 27.8 & 7.7 \\
\hline 5 & $\begin{array}{l}\text { The semester system does not } \\
\text { suit in our social, political and } \\
\text { administrative (within the } \\
\text { institution) set-ups. }\end{array}$ & 16.7 & 33.3 & 37.5 & 12.5 & 14.8 & 51.2 & 29.2 & 4.8 \\
\hline 6 & $\begin{array}{l}\text { The semester system has } \\
\text { promoted the standard and } \\
\text { knowledge structure of the } \\
\text { students }\end{array}$ & 25 & 50.0 & 20.8 & 4.2 & 27.8 & 37.8 & 20.1 & 14. \\
\hline 7 & $\begin{array}{l}\text { Do you think that females get } \\
\text { more favor in semester system? }\end{array}$ & $34.8^{*}$ & $34.8^{*}$ & $17.4^{*}$ & $13.0^{*}$ & 24.4 & 36.8 & 30.1 & 8.6 \\
\hline 8 & $\begin{array}{l}\text { Teachers try to influence } \\
\text { students when they fill in form for } \\
\text { their assessment }\end{array}$ & ** & & & & 27.3 & 41.6 & 19.6 & 11.5 \\
\hline
\end{tabular}

Note: Strongly Satisfied (SS), Satisfied (S), Dissatisfied (DS) and Strongly Dissatisfied (SD)

* Most of the teacher did not answer this question. Therefore, $\mathrm{N}=23$ instead of $\mathrm{N}=48$

** This question was not ask the teachers 
As far as the first item of the table is concerned that is related to the relevancy of the present curriculum to produce desired skills in students to meet the requirement of the market, both teachers and students responded positively towards this aspect. The teachers showed their strong satisfaction by $25 \%$ and satisfaction by a relatively high percentage of $45.8 \%$. The students showed their opinion by $27.8 \%$ as strongly satisfied and $51.7 \%$ as satisfied for this item. However, relatively more percentage of teachers $(29.2 \%)$ showed their dissatisfaction with this aspect as compared to students which is $20.6 \%$ (after adding percentages of students on dissatisfaction and strongly dissatisfaction).

Evaluation is a highly significant aspect of the educational process. Teachers are the sole person who handles assessing and evaluating the achievement of students and award grade that have the lifelong impact. Fairness and transparency are the spirits of this process.

The responses of teachers on item- 2 of the above table-4 delineate their strong satisfaction with $45.5 \%$ and satisfaction with $54.2 \%$ on being fair in evaluating students' performances. No percentage of teachers went against this aspect. The students also rated the fairness of the teachers in evaluating the progress of students with $14.4 \%$ for strong satisfaction and $59.3 \%$ for satisfaction. However, $23.4 \%$ of students recorded theirs dissatisfied against the fairness of teachers in evaluating the students' progress.

Both teachers and students also agreed that implementation of semester system promoted the authoritative attitude of teachers. The results in Table-4 under item-3 reveal that $29.2 \%$ of teachers and $26.8 \%$ of students strongly believed while $54.2 \%$ teachers and $56 \%$ of students agreed that teachers went more authoritative after the implementation of semester system. So, a substantial majority of both teachers and students evaluate teachers' behavior as being more authoritative in semester system environment.

Semester system bestowed more powers on the teachers and how they use these powers is the concern of the item- 4 of the table- 4 . In case of teachers, $25 \%$, and $54 \%$ responses are for strongly satisfied and satisfied while $8.3 \%$ and $12.5 \%$ of responses are dissatisfied and strongly dissatisfied respectively. The students with $17.2 \%$ and $47.4 \%$ of responses approved the statement as strongly satisfied and satisfied. However, more percentages of students, $27.8 \%$ for dissatisfaction and $8.3 \%$ for a strongly dissatisfaction-a total of $36.1 \%$, disagreed with the statement. This percentage, $36.1 \%$, is more than that of teachers' collective response, $20.8 \%$.

A system cannot work beyond the social influences of its society. The society provides the environment that decides the working patterns within a system. If a system is borrowed from other society, then some changes will have to be made in the implementation of that system according to the very nature of the society otherwise the system will be misfit and will not produce viable consequences. Semester system has not developed indigenously in Pakistan, but it is borrowed from most developed societies. The responses of the teachers and students on the suitability of the semester system in Pakistani social, political and administrative set-ups show almost similar results. Table-4 under item 5 reveals that $16.7 \%, 33.3 \%$ of teachers viewed semester system as unsuitable and strongly unsuitable while $37 \%$ and $12.5 \%$ viewed it suitable and strongly suitable in socio-administrative set-ups of educational institutions. However, more percentages of students $14.8 \%$ and $51.2 \%$ admitted the unsuitability of semester system as relatively less strongly and more strongly in our 
environment while a low percentage $29.2 \%$ of students showed dissatisfaction with the statement, they viewed the semester system suitable for our environment.

In table-4 under item-6, the sizable percentages, $25 \%$ and $50 \%$, of teachers as well as $27.8 \%$ and $37.8 \%$ of students reflected their strong satisfaction and satisfaction respectively with the fact that semester system has promoted the standard and knowledge structure of the students. On the other hand, more students with $20.1 \%$ of responses were dissatisfied and $14.4 \%$ strongly dissatisfied with the statement than teachers with $20.8 \%$ for dissatisfied and $4.2 \%$ for strongly dissatisfied respectively.

The data against the item-7 of the above table-4 shows that equal percentages of $34.8 \%$ responses of teachers admitted very strongly and strongly respectively that female students get more favor in semester system as compared to male students. The students favored the statement with percentages of $24.4 \%$ for strongly satisfied and $36.8 \%$ for satisfied. The students with more percentage of responses of $30.1 \%$ for dissatisfaction and $8.6 \%$ for strongly dissatisfied with the statement. The trend of low percentages of students against this aspect of favoring female students was because more female students went against the statement.

In the itme-8 of table-4, the students disclosed that teachers influence them while getting their remarks in their favor in the evaluation form to be filled in by the students for their evaluation. $27.3 \%$ and $41.6 \%$ of respondent students went for the statement very strongly and strongly while $19.6 \%$ and $11.5 \%$ of responses were dissatisfied and strongly dissatisfied respectively.

\section{Impingements on Working Environment in Semester System}

This part will deal with those factors that influence teachers directly or indirectly regarding their working in the semester system. These factors are related to both internal and external environments of the institution.

\subsection{Stress and Anxiety in Semester System}

The table- 5 indicates that teachers are under more stress in semester system than the annual system. In fact, the condition of working environment in semester system is different from an annual system. The universities were running the annual system for a very long time. However, the universities did not modify the system and provide the facilities according to the requirement of the semester system that created many problems for teachers. The teachers pointed out some main reasons for their stress as follows:

1. Overburden

a) Evaluation of papers, assignments,

b) Supervising research,

c) Teaching more classes

d) Conducting own research for profession development

e) Other useless administrative assignments

2. Less and untrained staff

3. More Students per class

4. Short time to cover the activities in stipulated time 
Table-5: Responses of Teachers regarding stress and anxiety in semester system than annual system.

\begin{tabular}{|l|l|l|}
\hline Item & Yes (in \%), N=48 & NO (in \%) N=48 \\
\hline $\begin{array}{l}\text { Stress in Semester System } \\
\text { than Annual System }\end{array}$ & $68.8 \%$ & $31.3 \%$ \\
\hline
\end{tabular}

\subsection{External Pressures that Affect Smooth and Just working?}

Unless the working environment is conducive, the maximum and productive performance of the personnel of any system can never be achieved. The university teachers highlighted those areas that affect the smooth and effective running of the semester system and, therefore, result in a low-performance level of teachers.

- Frequent Electricity breakdown

- Student Political and religious groups affiliated with different religio-political Parties and act as pressure groups

- Relatives of students who work in the same institution

- Primarily, Internal politics of department

- Country's political instability

- Lack of infrastructure and teaching aids

- Unnecessary delay in dealing with various requests either to establishment and administration.

- Favoritism and delay in due promotions

- Social \& Political pressure for good grades of students

- Internal politics of teachers

- Pressure from Head of Department to relax the student evaluation criteria

- Authoritative pressure

- Politics of University staff

\subsection{Fending Off the External Pressures/ Influences}

The responses in the above table show that no percentage of respondent teachers went beyond the 80 to fend themselves off these external pressures. The maximum percentage of the teachers who could avoid these negative influences ranged from $60-80 \%$. Just take one-factor electricity break down for 12-18 hours in a day. How the teacher can use computer, internet, conduct experiment, deliver the lecture and more.

Table-6: How much can teaches avoid these external pressures/influences?

\begin{tabular}{|l|l|l|l|}
\hline Item & $\begin{array}{l}\mathbf{1 0 - 3 0} \% \\
\text { (in \%) N=48 }\end{array}$ & $\begin{array}{l}\mathbf{4 0 - 5 0 \%} \\
\text { (in \%) N=48 }\end{array}$ & $\mathbf{6 0 - 8 0 \%}$ \\
\hline $\begin{array}{l}\text { Fending off the external } \\
\text { pressures/ influences }\end{array}$ & $16.7 \%$ & $37.5 \%$ & $45.8 \%$ \\
\hline
\end{tabular}




\subsection{Priority of Departmental or University Administration}

The teachers also pointed out that the priority of departmental or university administration is to run the system calmly but how? This is what the teachers disclosed the strategy through their responses as follows:

- No compromise for maintaining standard of education $20.8 \%$

- Compromise to avoid any unrest or preference to maintain rest and smooth running

An imaginary situation was put before the teachers requesting to visualize a situation when you taught the class with professional commitment to promote deep understanding of the students. You designed the test on the basis of what you taught to the class but the students could not achieve good grades and started agitating. How the administration would advise you to deal the situation. The responses of teacher make it clear in the following:

- Stand with you for your decision

$29.2 \%$

- Convince you to adopt some compromising attitude.

$29.2 \%$

- Advise you to opt such strategy to avoid such situation in future

$41.7 \%$

\section{Conclusion}

The forgoing results and discussion highlights details of how students and teachers feel towards different aspects of semester system. The functioning of every system seeks its guidance from a certain philosophy, and its success depends on how it is being run by its actors. Also, the facilities and support a system provides to the people responsible for its functioning and their attitudes collectively produce results. If it is being run according to what its philosophy suggests, then the consequences will be desirable.

The results reveal that the requirements to run the semester system in its real sense have not been provided. Although the reasons pointed out by the teachers that affect the regularity and full coverage of syllabus cannot be denied but there is another aspect that also contributes which is a power play in the system. Those teachers who enjoy the power by having authority due to their high ranks or political influence do not bother working norms.

The results mention the need to change the administrative style that is presently is authoritative. Lack of proper monitoring system makes the participants of a system responsible free. The teachers pointed out the inexistence of effective monitoring system.

Lack of staff especially the untrained staff, unnecessary delay in decision making and overburdened teachers are those aspects that hinder the smooth running of the semester system. The political pressures, unjustified administrative and management policies, security problems as revealed in the results limit the teachers to work with their will, capacity, determination and confidence. How a teacher without comfortable mind and body can perform properly and contribute to the better outputs. Such teacher would pass on, although cannot be justified, the biases to the students that they face during their duties. This may be intentional or unintentional, under some stress and anxiety, but it is what happening in the educational institutions.

The data also reflect that it seems very difficult for the teachers to go against the priority of the administration of keeping the environment of the institution smooth. For 
this objective, many compromises have to be made to counter the external and internal pressures and to hide the inefficiencies of the system.

In such environment, the semester system cannot be run with its zeal and zest but, it does not mean that we should switch to old annual or composite systems. The purpose to highlight the those areas of the system where reforms are more needed and is to provide data to policy and implementing authorities for better decisions towards more and more efficient and effective environment in which the semester system can better be implemented.

\section{References}

Burki, S. (2015). Pakistan: Daily life and social customs. In: Encyclopeadia Britannica

Geert-hofstede.com, (2015). Pakistan - Geert Hofstede. [online] Available at: http://geerthofstede.com/pakistan.html.

Hall, E. (1976). Beyond culture. Garden City, N.Y.: Anchor Press.

Hofstede, G. (1991). Cultures and Organizations: Software of the Mind. London, UK: McGraw-Hill, p.262.

Hofstede, G. (1994). Cultures and organizations. London: HarperCollins.

Hofstede, G. (2001). Culture's consequences. Thousand Oaks, Calif.: Sage Publications.

Lewis, R. (2006). When cultures collide. Boston: Nicholas Brealey International.

Oplatka, I. (2004). The principalship in developing countries: context, characteristics and reality. Comparative Education, 40(3), pp.427-448.

Pabla, M. (2014). A Paradigm shift from Semester system to Annual System. PARIPEX - Indian Journal of Research, [online] 3(4), p.173. Available at:

http://worldwidejournals.com/paripex/issues.php?m=April\&y=2014\&id=30 [Accessed 7 Sep. 2015].

Parsons, T. (1949). Essays in sociological theory, pure and applied. Glencoe, III.: Free Press. 